\title{
Lessons and challenges for the recycling sector of Brazil from the pandemic outbreak of COVID-19
}

\author{
Ronei de Almeida ${ }^{1}\left[\right.$. Roberta Guimarães de Souza ${ }^{2} \cdot J_{u a c y a r a}$ Carbonelli Campos ${ }^{1}$
}

Received: 16 December 2020 / Revised: 16 April 2021 / Accepted: 21 May 2021 / Published online: 14 June 2021

(c) Zhejiang University Press 2021

\begin{abstract}
The 2019-2020 coronavirus pandemic imposed unprecedented challenges in Brazilian governance sectors, mostly in the waste management system. Herein, we analyse the main challenges of the recycling sector in Brazil to cope with this scenario. Understanding difficulties during the pandemic outbreak of COVID-19 can help improve waste recycling in the post-pandemic period in Brazil and other developing nations that face similar issues. The current pandemic exposed the deficiencies of this system, and some important lessons can be learned. Recommendations are drawn to advance the proper management of recyclables in the country. The Government must increase total investments in the recycling industry's infrastructure and support local recycling initiatives during a public health crisis and beyond. In sum, this paper strengthens the idea that waste segregation at the source and selective collection will not be sufficient without massive investments in the recycling sector's infrastructure. The future challenge includes strengthening the economic markets for recycled materials.
\end{abstract}

\section{Graphic abstract}

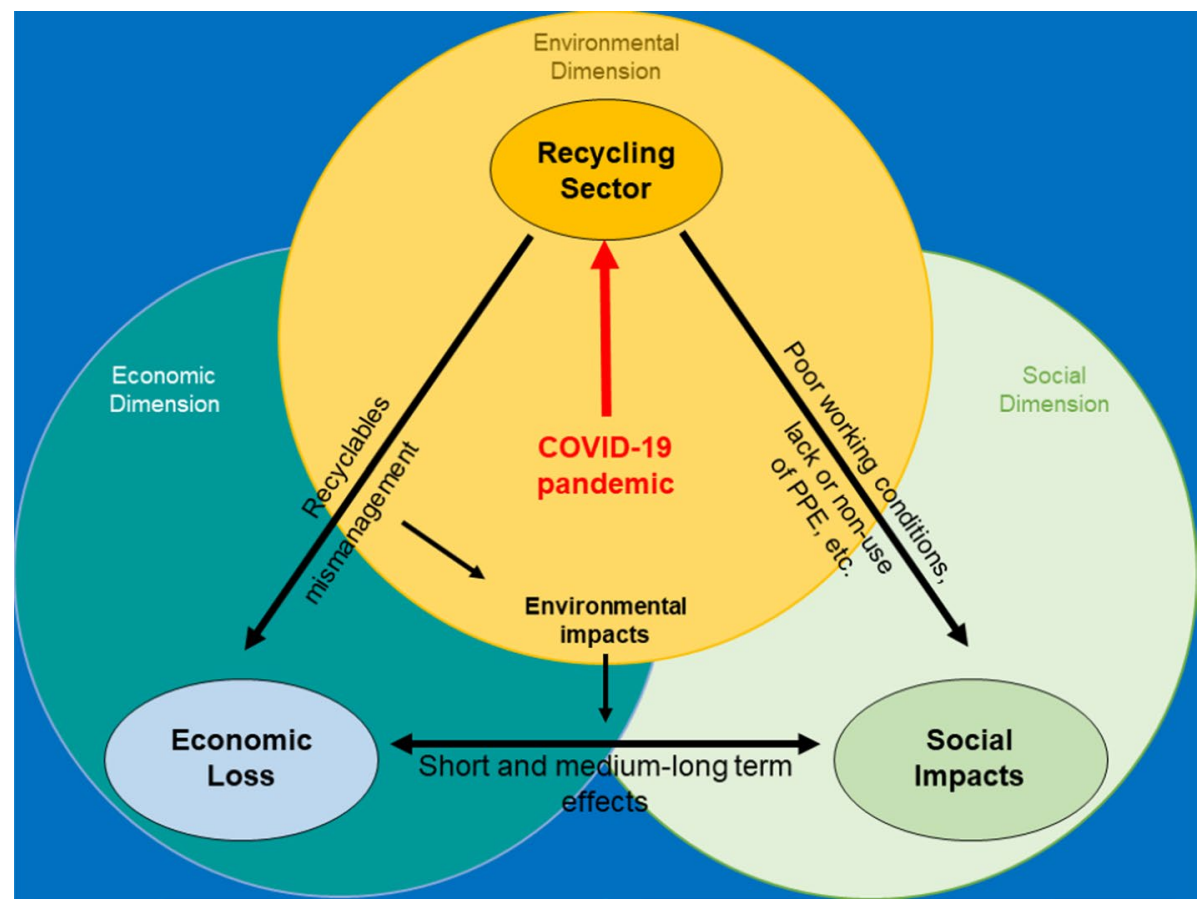

Ronei de Almeida

ronei@eq.ufrj.br

1 School of Chemistry, Inorganic Processes Department, Federal

2 CoClima, Av. Alfonso Balthazar da Silveira 339, Recreio dos University of Rio de Janeiro. Av, Athos da Silveira Ramos 149, Bandeirantes, Rio de Janeiro 22790-710, Brazil Ilha do Fundão, Rio de Janeiro 21941-909, Brazil 
Keywords Coronavirus $\cdot$ Developing countries $\cdot$ Informal sector $\cdot$ Recycling $\cdot$ Selective collection $\cdot$ Waste management

\section{Introduction}

The ongoing pandemic modified the scenario around us and has shaken the foundations of several sectors. Among the waste management issues, recycling has been one of the most challenging problems. During the pandemic period, an increase in recyclables waste was recorded, mainly from e-commerce and food delivery services, thus increasing the demand of the recycling sector.

It is worth noting that from March to May 2020, during the most strict quarantine period and stay-at-home recommendations issued nationwide, the Brazilian paper and cardboard industry recorded a $3.2 \%$ decline. Conversely, from June to September, with the gradual re-opening of businesses, the sector grew by $15.4 \%$ compared to the same period in 2019 [1]. A similar tendency was noticed in packaging consumption and waste generation, which imposed new challenges concerning cities' waste management systems, considering that paper/cardboard and plastic waste represents about $65 \%$ of recycling materials in Brazilian recycling initiatives [2].

From March to October 2020, São Paulo Municipality (Brazil) collected 62,866 tons of recyclables, an increase of $22 \%$ to the same period in 2019 [3]. Brazilian researchers conducted a study that shows a decline (ca. 8\%) in household waste generation during the COVID-19 period (January 2020 to July 2020) in a city located in São Paulo State (Brazil) when compared to the same period in 2019. In contrast, they observed a huge increase in the amount of paper/cardboard waste collected from April to June 2020 (459\%-151.7\%) [4]. However, as a result of the pandemic, the Brazilian recycling system has been restricted to prevent infection risks. Zambrano-Monserrate et al. [5] point out that the growth of waste generation and the reduction of recycling have emerged as negative impacts of COVID19. In developed nations, waste management has also been restricted. Italy has prohibited infected residents from sorting their waste, and some cities of the United States of America (USA) have stopped their recycling programmes [5].

In fact, some of our new habits tend to hold on for a long time in the post-pandemic world. For example, online shopping will probably continue to rise as many consumers get used to the benefits in terms of practicality and costs [6]. Consequently, this rise may increase the volume of waste and related recycling and disposal issues. On the other hand, the waste management system from developing countries such as Brazil may not be able to handle this scenario.
The impact of COVID-19 on the recycling sector has been under-discussed, particularly in developing nations. The increase in waste generation and the scarcity of recycling programmes may produce further challenges in the post-pandemic period and, therefore, constitute a reason for concern. Surprisingly, there are little published data on the effects of COVID-19 on the recycling chain. In this context, we examine the recycling sector of Brazil during the pandemic outbreak of COVID-19. This article analyses the published literature and information from government and non-government organizations' websites. Identified deficiencies are discussed, and recommendations are drawn. Studies published in Portuguese usually stay out of reach of the foreign community. Therefore, reports published in English and Portuguese language were selected for this article. This work provides an important opportunity to inform and support authorities with solutions and practical implications.

\section{Materials and methods}

Brazil is the largest Latin American country, with an area of $850 \mathrm{M}$ ha and a population of about $212 \mathrm{M}$ of people. The country is composed of 26 States and one Federal District, which are grouped into five regions: North, North-east, South-east, South, and Mid-east, comprising a wide range of socio-economic conditions [7].

This work analyses data from government and nongovernment Brazilian institutions, e.g., "Brazilian Association of Environmental Engineering and Sanitation" (Abes), "National Sanitation Information System" (SNIS), "Brazilian Corporate Commitment to Recycling" (CEMPRE), and "Brazilian Association of Public Cleaning and Special Waste Companies (Abrelpe), to capture a holistic viewpoint and support the study's discussion on the recycling system during the pandemic and post-COVID in Brazil.

Scientific literature was collected from the database of Web of Science, Science Direct, and Scopus. A combination of the following search keywords was used to find the scientific literature: "coronavirus", "COVID-19", "pandemic", "recycling", and "waste management". Our study was exploratory and interpretative.

The paper is structured as follows: first, we show an overview of the recycling sector in Brazil. Second, the impacts of COVID-19 on this sector are discussed. Third, experiences overseas are examined. Finally, recommendations for the Brazilian recycling system are drawn. 


\section{Brazilian recycling sector}

According to the "Brazilian Corporate Commitment to Recycling" (CEMPRE) [8], Brazil has 858 recycling industries (22 aluminium centres, 27 paper recycling facilities, and 809 plastic recycling companies) (data of 2017). The Brazilian recycling companies produced $1.28 \mathrm{M} \mathrm{t} / \mathrm{y}$ of recycled products and had annual sales of $590 \mathrm{M}$ BRL (ca. 114 M USD) in 2019 [9].

Table 1 shows recycling data for the six regions of the country in 2018.

This table is revealing in several ways. First, it shows that recyclable waste collection systems have not yet been established in most Brazilian cities. Brazil has 5570 municipalities in total. Of the 3468 municipalities surveyed, only $1322(38.1 \%)$ offer some sort of selective collection. In contrast, 2146 municipalities (61.9\%) do not offer this service. Second, recycling initiatives are centralized in the South
(42.7\%) and South-east (42.8\%) regions. Together, the poorer regions of the country, i.e., North and North-east, account for $8.6 \%$ of selective collection systems.

Figure 1 depicts the number of Brazilian municipalities with selective collection from 1994 to 2018 and the gravimetric composition of the recyclable waste collected in 2018.

It is estimated that $30 \%$ of the collected wastes in Brazil are recyclables. On the other side, the recycling rate of municipal solid waste is estimated at $13 \%$ [11]. It should be emphasized that the recycling rate varies widely among the recyclable materials collected in the country. For example, concerning aluminum waste, the recycling rate is greater than $90 \%$ [12]. In the case of plastic, recent data show that only $1.28 \%$ is recycled [13] while the global average of plastic recycling is estimated at $9 \%$. For instance, the USA and the European Union (EU) recycle their plastic 34.6\% and $31.1 \%$, respectively $[13,14]$. During the COVID-19 pandemic, in addition to the discharge of disposable personal

Table 1 Recycling data from household waste collection systems in Brazil. Source: adapted from [10] with permission

\begin{tabular}{lllclll}
\hline Regional divisions & $\begin{array}{l}\text { Total number of } \\
\text { municipalities } \\
\text { surveyed }\end{array}$ & $\begin{array}{l}\text { Number of } \\
\text { municipalities } \\
\text { with recycling } \\
\text { initiatives }\end{array}$ & $\begin{array}{l}\text { Total recyclable } \\
\text { waste collected in } \\
2018\left(\mathrm{t} \mathrm{year}^{-1}\right)\end{array}$ & $\begin{array}{l}\text { Recyclable waste } \\
\text { collected per } \\
\text { capita in 2018 (kg }_{\left.\text {inhab }^{-1} \text { year }^{-1}\right)}\end{array}$ & $\begin{array}{l}\text { Number of waste } \\
\text { pickers coopera- } \\
\text { tives and associa- } \\
\text { tions }\end{array}$ & $\begin{array}{l}\text { Total number of } \\
\text { formal workers in } \\
\text { the recycling sector }\end{array}$ \\
\hline North & 233 & $33(2.5 \%)$ & $51,174.4$ & 8.0 & $53(4.3 \%)$ & $1685(6.2 \%)$ \\
North-east & 799 & $81(6.1 \%)$ & $157,570.1$ & 8.6 & $165(13.4 \%)$ & $4086(15.1 \%)$ \\
South-east & 1199 & $566(42.8 \%)$ & $620,168.4$ & 10.2 & $513(41.6 \%)$ & $10,328(38.2 \%)$ \\
South & 962 & $564(42.7 \%)$ & $707,772.7$ & 34.2 & $389(31.6 \%)$ & $7959(29.4 \%)$ \\
Mid-east & 275 & $78(5.9 \%)$ & $130,929.6$ & 13.8 & $12(9.1 \%)$ & $3005(11.1 \%)$ \\
Brazil & 3468 & $1322(100 \%)$ & $1,667,615.2$ & 14.4 & $1232(100 \%)$ & $27,063(100 \%)$ \\
\hline
\end{tabular}

Fig. 1 Number of Brazilian municipalities with selective collection from 1994 to 2018 and the gravimetric composition of the recyclable waste collected in 2018. Source: Adapted from CEMPRE [8] with permission

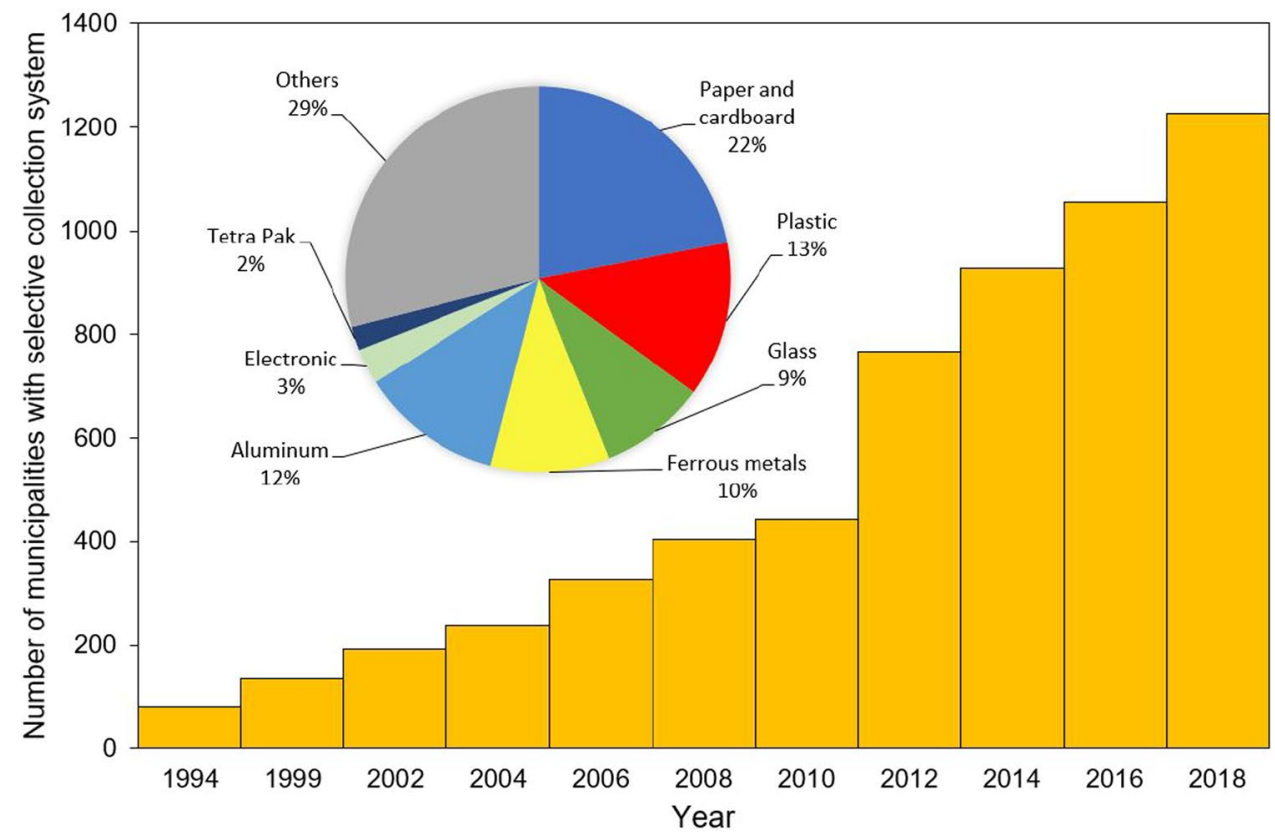


protective equipment (PPE) (e.g., face masks and gloves) [15], there was a rise in the use of food delivery services and e-commerce. As a result, plastic waste increased, shedding light on plastic recycling and disposal issues [16].

Reverse logistics was introduced as a legal mechanism in Brazil by the National Policy on Solid Waste-NPSW (Federal Law No. 12,305/2010) [17]. In 2015, a Sectorial Agreement was signed, according to which industries must ensure the proper final destination of post-consumption packagings: reuse, recycling, treatment, and disposal [18].

In general, according to the NPSW, public governance and city stakeholders should support the recycling associations and waste-pickers, while industries must ensure reverse logistics of post-consumption packagings. However, similarly to other developing nations, the Brazilian recycling system's weaknesses include technical and financial difficulties, lack of investments, and political discontinuity. Furthermore, in low- and middle-income countries such as Brazil, the recycling sector comprises small companies that generally carry out collection, transportation, separation, classification, and commercialization [19]. The scarcity of recycling companies located close to the production chain increases transportation costs and hampers recyclables' proper final destination.

It should also be noted that the majority of selective collection programmes operated by Brazilian municipalities use the door-to-door scheme, which is mostly dependent on citizens' behaviours to segregate household waste fractions. The precarious transportation infrastructure and the lack of good practices for waste separation make the collection expensive, representing a barrier for several municipalities to improve their recycling rates. Paschoalin Filho et al. [20] reported that the low adhesion of the Brazilian citizens to selective collection programmes is the greatest obstacle to a further expansion of recycling initiatives. Economic loss due to the wrong source separation is estimated at $194 \mathrm{k}$ and $396 \mathrm{k}$ in Curitiba (PR) and Brasília (DF) [21]. Thus, the creation of small volume delivery stations similar to those from developed nations, together with awareness-raising campaigns to boost citizens' motivation on the correct separation and cleaning of materials, could be pivotal to improve the recovery of recyclables [22].

It is estimated that 8B BRL (ca. 1.55B USD) per year is lost in Brazil due to the inappropriate destination of recyclables to landfills [8]. It is important to highlight that, in Brazil in 2018, 29.9 Mt (40.5\%) of wastes were disposed of in dumpsites and non-sanitary landfill, and 6.3 Mt (8\%) were not even collected, being possibly disposed of inadequately [23].

The landfilling of waste occurs worldwide, particularly in developing nations where there are a scarcity of recycling infrastructure, that is, transportation, material recovery facilities (MRFs) and, waste processing plants. It is estimated that $70 \%$ of waste globally collected ends up in landfills or dumpsites [24]. However, less than $30 \%$ of waste is landfilled in high-income countries such as Germany, France, UK, and Austria [25], which favours recycling (29\%), incineration (22\%), and composting (6\%) [26]. Landfilling is diminishing in European countries for several reasons, according to Agamulhu and Law [26], two of which are the ban on organic waste landfilling and a high landfill tax. In this sense, Brazil could learn from developed countries' experiences to boost organics recovery and recycling.

In 2020, Brazil approved the Federal Law No. $14,026 / 2020$ [27] (new sanitation regulatory framework). As a result, municipalities could create a fee for waste management. Currently, 53\% of Brazilian municipalities do not have a tax collection system to support their waste management infrastructure [28]. It is expected that the creation of a disposal tax may also contribute to the promotion of waste reduction and reuse, which should be prioritized in the waste management hierarchy.

Based on the aforementioned information, identified challenges for the recycling sector in Brazil are summarized in Table 2.

\section{The impact of the pandemic on the Brazilian recycling sector}

\section{Recyclables generation and management}

The "Brazilian Association of Public Cleaning and Special Waste Companies" points out that, during the early COVID-19 outbreak, in April and May, there was a 6\% and 9\% decrease in waste generation [29]. The per capita waste generation in Brazilian States capitals during March, April, and May was $0.72,0.66$, and $0.65 \mathrm{~kg} / \mathrm{inhab} / \mathrm{d}$, respectively. In June, after the loosening of social distancing measures, there was a slight increase in total municipal waste generated (ca. 2\%). The per capita waste generation was then estimated at $0.69 \mathrm{~kg} / \mathrm{inh} a b / \mathrm{d}$. On average, however, there was a $28 \%$ growth in the amount of recyclable material collected, such as glass, paper/cardboard, and plastic wastes [29, 30]. This scenario is likely related to an increase in the paper/cardboard and plastic packaging waste originated both in online shopping and food delivery services [31]. It also suggests a change in citizens' consumption behaviour during the disease outbreak.

On the other hand, in Brazil, the current crisis has hampered the proper destination of recyclable materials and has disrupted the system of several recycling industries, as illustrated in Fig. 2. Due to the social distancing measures, the Brazilian recycling system has been restricted to prevent infection risks. From 23 March to 24 April 2020 , more than half of the national recycling initiatives 
Table 2 Identified challenges for the recycling sector in Brazil

\begin{tabular}{|c|c|c|}
\hline Dimension & Main challenge & Associated sub-challenges \\
\hline Political & Political will & $\begin{array}{l}\text { Emphasise waste prevention and reuse over other waste management strategies } \\
\text { Strengthen incentives for households, businesses and local authorities to reduce waste (tax collection } \\
\text { system, pay-as-you-throw programmes) } \\
\text { Formulation of specific regulations for recycling } \\
\text { Lack of strict regulation to avoid the mismanagement of recyclables } \\
\text { Guarantee tax justice and legal security for the recycling sector } \\
\text { Social inclusion policies }\end{array}$ \\
\hline Economic & Lack of investments & $\begin{array}{l}\text { Scarcity of infrastructure } \\
\text { Technical difficulties (e.g., compatible equipment with technical standards, outdated machines, and } \\
\text { skilled labor) } \\
\text { Increase selective collection } \\
\text { Support to cooperatives and informal recyclers } \\
\text { Improvement of working conditions }\end{array}$ \\
\hline Environmental & Solid waste management & $\begin{array}{l}\text { Increase of solid waste generation } \\
\text { Promotion of proper final destination of waste } \\
\text { Management and recovery of dumpsites and non-sanitary landfills }\end{array}$ \\
\hline Societal & Consumers behaviour & $\begin{array}{l}\text { Increase in communication and population awareness } \\
\text { Reduction at source and sustainable consumption } \\
\text { Diffusion of good practices for waste segregation (e.g., better at-home separation, reduce recyclables } \\
\text { contamination at the source) }\end{array}$ \\
\hline
\end{tabular}

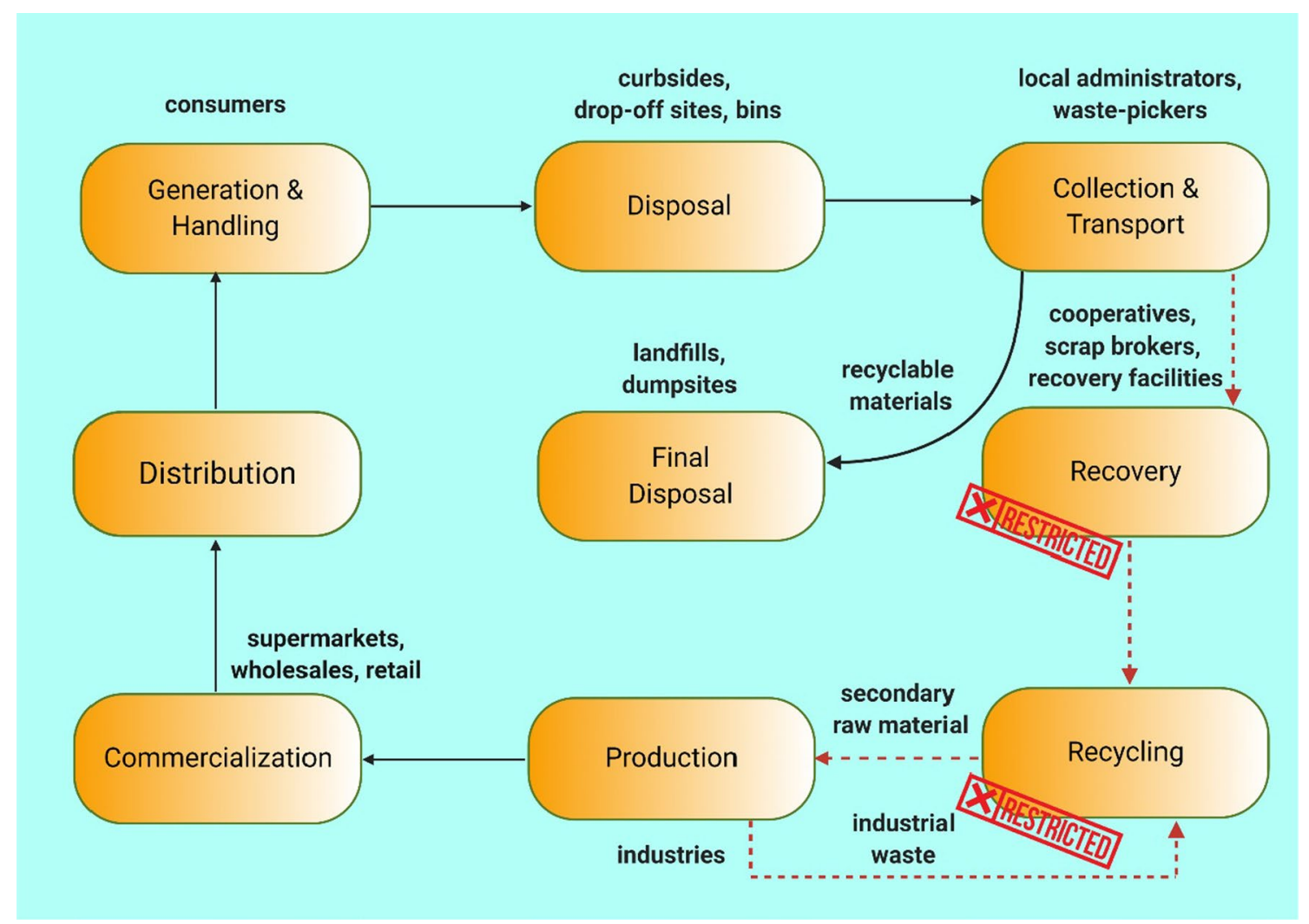

Fig. 2 Diagram of the recycling system and the mismanagement of recyclable materials during the COVID-19 scenario in Brazil. Source: Based on Conke [21] with permission 
reported interruption of their activities [32]. During this period, it was observed a reduction of 16,736 tons of recyclable materials collected by selective collection, which represents an economic loss of about 1,243,725 USD per month for cooperatives and waste-picker associations in Brazil [33]. When extrapolated for 1 year, this quantity is equivalent to $15 \mathrm{M}$ USD and represents about $13 \%$ of recycling companies' annual sales in 2019. Urban and Nakada [34] reported that, considering recycling suspension for 30 days during the outbreak of the pandemic, the revenue loss due to the disposal of recyclables in landfills in Brazilian cities such as Manaus (AM), Salvador (BA), São Luís (MA), Brasília (DF), Belo Horizonte (MG), and Florianópolis (SC) was estimated at 119 k, 73 k, 12 k, $193 \mathrm{k}, 46 \mathrm{k}$, and $57 \mathrm{k}$ USD, respectively. Recyclable materials are now, more than ever, being collected and landfilled. A similar situation has been observed in Asian countries such as India and Indonesia [35, 36].

Due to the increase in online shopping and the need to supply the health sector's demand, the pandemic has required reinforcement and adaptability of logistical systems [37]. As reported by Yu et al. [38], logistics for medical waste management become a challenge for several nations. Concerning the Brazilian recycling sector, poor transportation infrastructure associated with long distances to be running and infection risks related to the collection, transportation, and processing of recyclables have hampered the effective reverse logistics of postconsumption materials.

During the peak of the pandemic in Brazil, another situation reported was the growth of stored recyclables in cooperatives. The recycling industries were not buying recyclable materials for two reasons. First, due to the reduction of industrial activity and second, due to the fear that the materials were contaminated. However, after the gradual return of activities, several recycling industries have faced scarcity of secondary raw material given an increasing demand.

A recent case reported by Zhou et al. [39] shows that from January to March 2020, the waste-to-material industry in China dropped significantly $(-28 \%)$, comparing their turnovers in 2019. The decline in profits of waste companies was estimated at 8.6 B USD. The rise of logistic costs, delay of receivable accounts, and the reduction of the benefit from secondary raw material during the pandemic outbreak could be contributed to the economic loss [39].

\section{The situation of waste professionals in Brazil}

Recent evidence indicates that SARS-CoV-2 can survive on the surface of recyclable materials (e.g., paper/cardboard, plastic, glass, and metal wastes) [40]. Studies performed in Brazil, Greece, India, Iran, and Pakistan have shown that pathogens in polluted wastes can be directly traced to a substantial prevalence of virus infection in waste professionals [41]. Such evidence has raised concerns about the safety and health of workers in the waste sector, particularly of waste-pickers-informal workers of the recycling chain, as discussed in Mol and Caldas [42].

A study performed by the "Brazilian Association of Environmental Engineering and Sanitation" (Abes) [33] reveals that the rate of COVID-19 confirmed cases per 100,000 inhabitants among waste workers in Brazilian capitals is up to 5.5-fold higher than that of the rest of the Brazilian population (Table 3 ).

As shown in Table 3, considering the 82,213 formal workers of the waste sector in Brazil, 178 cases of contamination were confirmed until April 30th, 2020. Of that number, 13 workers died, representing a death rate of 15.8 per 100,000 inhabitants. It should be emphasised that wastepickers-approximately 229,568 informal workers, who are responsible for a significant amount of the recyclable materials collected in Brazil (around 90\%), were not included in this survey, and they entirely lack in care during the pandemic [43].

A second survey was carried out between 6 May and 29 May 2020. The waste professionals not essentially linked to urban cleaning services in the municipality of Rio de Janeiro (RJ), i.e., cleaning hospitals, cleaning schools, and

Table 3 Number of COVID-19 confirmed cases and deaths among Brazilian waste professionals in Brazilian capitals (accumulated cases up to April 30 and May 31, 2020). Adapted from [32] with permission

\begin{tabular}{lllllll}
\hline Survey date & & Population & Total cases & Deaths & $\begin{array}{l}\text { Rate of contamination/ 100,000 } \\
\text { inhabitants (Average) }\end{array}$ & $\begin{array}{l}\text { Rate of deaths/ } \\
100,000 \text { inhabitants } \\
\text { (Average) }\end{array}$ \\
\hline April 30, 2020 & Brazil & $212,000,000$ & 87,187 & 6006 & 41.1 & 2.8 \\
& Waste sector & 82,213 & 146 & 13 & 178 & 15.8 \\
May 31, 2020 & Brazil & $212,000,000$ & 514,200 & 29,314 & 449 & 13,7 \\
& Waste sector & $61,064^{*}$ & 475 & 10 & 778 & 16,4 \\
\hline
\end{tabular}

*Workers not essentially linked to urban cleaning services in the municipality of Rio de Janeiro (RJ) and waste-pickers linked to cooperatives from the city of Curitiba (PR) were included in this survey 
community workers working in slums were included in this survey, as well as the waste-pickers linked to cooperatives from the city of Curitiba (PR). In this survey, it was considered only the contingent of professionals allocated in the services for which the information was requested in RJ-9486 workers. In the first research, in RJ, 22,314 workers were considered according to information from the SNIS [10]. In PR, the quantity reported was 3614 workers, which included waste-pickers connected to cooperatives. It was considered 2114 professionals in the previous study. Considering the 61,064 workers of the waste sector in Brazil, 475 cases of contamination were confirmed until May 31st, 2020. A death rate of 13.7 was registered. Several factors contribute to this scenario, including non-use of PPE, contact with infected and poorly conditioned waste, negligence during work routine, and precarious working conditions.

\section{International experience}

It must be noted that, during the COVID-19 pandemic, recycling industries in developed nations are experiencing similar challenges to those experienced in Brazil. A detailed evaluation of the situation overseas could help Brazilian recycling industries adopt successful approaches. Examples, which the Brazilian Government could learn from, include the following:

(i) USA

"Pellegrini said residential recycling costs are frequently subsidized by commercial recycling customers, who dump far larger loads and pay based on the amount of material they're delivering. With the loss of that material stream, the residential recycling side of the business may not cover itself, even if all ratepayers continue paying their bills." (Source: Staub [44]_April 28, 2020).

(ii) Canada

"RECYC-QUÉBEC enhanced the support program for curbside recycling MRFs to help MRFs cover unexpected and necessary additional costs required to meet public health and workplace health and safety recommendations. An additional boost of $\$ 20,000$ maximum per MRF is possible for the next deposit date (July 31,2020 ) in order to cover, partially or entirely, expenditures excluding taxes for protective equipment and measures to limit COVID-19 propagation risks. ... MRF managers were very visible in the media to inform citizens about protective measures implemented and to remind them that good sorting at the source is very important." (Source: OWMA [45]—May 28, 2020). (iii) $\mathrm{EU}$

"Glass and paper recycling were definitely impacted. The value chains have been interrupted and the reduced collection services also meant reduced quantities of recyclable material. A lot of the recycling plants have been closed during the lockdown and the different waste fractions remained at the transfer stations. ... Unfortunately, the closure of bring centers often led to an increase of illegal disposal of waste which has been reported from the Netherlands, Belgium, UK, and Portugal. Hence, a lot of municipalities put efforts went into communication, asking citizens to keep specific items such as batteries, WEEE, lamps at home until after the pandemic." (Source: IE [46]—July 02, 2020).

In the USA, the RECYCLE Act was introduced in November 2019. The legislation authorized 15 M USD per year over 5 years to States and stakeholders aiming to boost recycling activities [47]. The main objective was to increase the recovery of recyclable materials and promote awareness programmes to decrease contamination on the recycling chain. More recently, recycling stakeholders, particularly, plastic and glass industries, demand the inclusion of recycling infrastructure in the National coronavirus aid packetthe RECOVERY Act. The legislation would allocate $500 \mathrm{M}$ USD in grants to municipalities to promote improvements in recycling infrastructure. Recyclers argue that these funds could be used to improve collection systems and the processing of recyclables [48].

Canada and countries of the EU have invested in communication to increase public awareness. The major aims are to reduce coronavirus propagation during waste handling and promote proper waste segregation at the source. Besides, Member States of the EU can offer full assistance, including grants of up to $800 \mathrm{k}$ EUR and public loan guarantees. These mechanisms should be used to ensure that stakeholders of waste management systems have access to the funding required to tackle the emerging crisis [49].

\section{Important lessons for the Brazilian recycling sector}

The current pandemic exposed the deficiencies of the Brazilian recycling system, and some important lessons can be learned. Detailed recommendations for the Government and stakeholders are provided below.

\section{Recommendations for the Brazilian government}

As already discussed, the local authorities should include in their agenda communications and awareness campaigns via the Internet, television, and public services announcements 
during public health emergencies and beyond. Concomitantly, Governments at all levels must support and promote educational, research, and training programmes.

However, while awareness campaigns may bring attention to the issue, they are not long-term solutions to infrastructure problems. The pandemic reveals that the Brazilian Government needs to increase total investments in the infrastructure of recycling and support local waste pickers associations. This could be done through mechanisms such as subsidies, tax justice, preferential tax treatment provisions for recycling companies, and legal security for waste-pickers cooperatives. Furthermore, it should be underlined that the recycling sector demands the modernization of current MRFs in Brazil. As discussed by Campos [50], unplanned facilities with outdated machines/equipment and poor working conditions are observed nationwide. Experiences in countries such as Japan, Sweden, Italy, and Turkey showed that governmental intervention is imperative for increasing the number of recycling plants [51].

The reallocation of the investment portfolio is also necessary to promote the decentralization of Brazil's recycling installation. Recycling initiatives, that is, selective collection, cooperatives, scrap brokers, and recovery facilities are centralized in the South and South-east regions. The scarcity of recycling systems favours the mismanagement of recyclable materials. There is no doubt that in the recycling chain, the infrastructure plays a decisive role [52]. The construction of roads to flow the recyclable materials and MRFs to recovery them could enable the return of post-consumption products to industries and manufacturers [6]. Hence, it would be possible to increase the recycling rate in the country. Finally, the Government must set strict regulations to promote reverse logistics and expand this system to other goods chains. Clear laws and strict regulations to avoid the recycling materials' mismanagement could help to sustain the reverse logistics in Brazil.

\section{Recommendations for recycling industries and stakeholders}

Industries need to cooperate financially with a system that supports recycling and proper waste destination. They should take responsibility for the life cycle of their products. From a circular economy perspective, industries could alter manufacturing processes to 1 . reduce the amount of waste generated, 2 . design more easily recycling packaging, 3. reuse discharged materials, and 4. use packaging waste as inputs. All packaging manufacturers and suppliers in Germany, for example, are entirely responsible for their waste and must comply with and fully fund a system that guarantees their recycling and recovery operations. The packaging chain has a logistics system for this purpose, which picks up household packaging in parallel with the current municipal waste collection systems. In this regard, the industry provided an arrangement of its responsibility (Green dot) to ensure the collection of packaging waste from all consumers and fulfil specific quotas of collection, sorting, and recycling. The fee paid to each product varies according to the weight and the type of material used in the package. This encourages and rewards companies with sustainable design strategies and innovation in their product development [53].

The future recycling scenario includes the formatting of innovative and robust business models and sustainable solutions in industries' achallenges, the replacement of extensive transportation of post-consumption materials over long distances with intermediate storage, depots, and material reserves can play a decisive role. Moreover, Brazil should diversify the transport modal, invest in automation and failure prevention. Besides, more innovative logistics systems enabled by Internet of Things (IoT), satellite technology, and artificial intelligence could save time, energy, and resource during recyclables management [54].

It must be pointed out that because of the pandemic, not only has economic growth slowed, but also fall in oil prices has led to a rise in the supply of cheap virgin plastic. Hence, the competitiveness of recycled plastic products is reduced [55]. Therefore, sensitivity to prices could emerge as a critical obstacle for recyclers.

Considering the demands of a new low-carbon and circular economy, changes in the production model are needed. In this context, recycling can play a key role. To this end, the sector needs to reduce contamination in the recycling stream, make the recycling processing system more efficient, and strengthen the economic markets for recycled materials. Regarding some types of plastic waste, there is no cost-benefit balance, and difficult to recycle. Solutions beyond the industry's current state are needed to handle complex compositions (e.g., multilayer plastics, adhesives, toxic components) and unavoidable contamination. In this sense, the development of innovative methods, improvements in existing technologies (e.g., pyrolysis, gasification), or innovative management schemes are required. Therefore, investments in research and development are imperative.

\section{Conclusions}

The COVID-19 pandemic exposes the deficiencies of the Brazilian recycling system and teaches some important lessons. During this episode, it was recorded an increase in the disposal of recyclable materials. On the other hand, the current socio-economic challenges of the recycling sector have intensified the mismanagement of recyclables, causing further economic loss and negative social impacts in Brazil. COVID-19 contamination among waste professionals was 5.5-fold higher than that of the rest of the Brazilian 
population during the pandemic outbreak, and economic loss was estimated at 1.24 M USD per month. This paper strengthens the idea that waste segregation at the source and selective collection will not be sufficient without massive investments in the infrastructure of the recycling sector, especially in less developed regions, considering that more than $85 \%$ of the recycling infrastructure is centralized in wealthier regions, i.e., South and South-east regions. Based on overseas experience, the Government and stakeholders must increase total investments in the recycling industry's infrastructure and support local recycling initiatives during a health emergency and beyond. The current study highlights recommendations based on the fundamental pillars of foreign recycling systems: additional investments and environmental education. Future challenges for the recycling systems lay on reducing contamination in the recycling stream, improve the processing system of recyclables, and strengthen the economic markets for recycled materials.

Acknowledgements Ronei de Almeida gratefully acknowledges the financial support received from Fundação Carlos Chagas Filho de Amparo à Pesquisa do Estado do Rio de Janeiro (Faperj) (Grant No. 200.065/2020) and Conselho Nacional de Desenvolvimento Científico e Tecnológico (CNPq) (Grant No. 165018/2018-6).

Author contributions Ronei de Almeida: conceptualization, investigation and data analysis; methodology; writing - original draft preparation; reviewing and editing. Roberta Guimarães de Souza: writingreviewing and editing. Juacyara Carbonelli Campos: supervision; funding acquisition.

Data sharing All data used in this study are publicly available and are referenced in the manuscript.

\section{Declarations}

Conflicts of interest The authors declare no conflict of interest.

\section{References}

1. AGENCY BRAZIL (2020) E-commerce and delivery increase in packaging consumption. https://agenciabrasil.ebc.com.br/econo mia/noticia/2020-10/comercio-eletronico-e-delivery-aumentamconsumo-de-embalagens [in Portuguese]. Accessed 27 Nov 2020.

2. Fidelis, R., Marco-Ferreira, A., and Antunes, L.C. 2020. Socioproductive inclusion of scavengers in municipal solid waste management in Brazil: practices, paradigms and future prospects. Resources, Conservation and Recycling 154: 104594. https://doi. org/10.1016/j.resconrec.2019.104594.

3. Cidade de São Paulo. 2020. Waste collected in the municipality. https://www.prefeitura.sp.gov.br/cidade/secretarias/subprefeituras/ amlurb/index.php? $\mathrm{p}=185375$ [in Portuguese]. Accessed 10 Dec 2020.

4. Ventura. K.S., Junior. B., and Xavier, V. et al. 2020. Analysis of COVID-19 impacts at the collection of municipal household, recyclables and healthcare wastes in the municipality of Araraquara (SP), Brazil [in Portuguese]. Brazil. Rev ESA.
5. Zambrano-Monserrate, M.A., Ruano, M.A., and Sanchez-Alcalde, L. 2020. Indirect effects of COVID-19 on the environment. Science of the Total Environment 728: 138813. https://doi.org/10.1016/j. scitotenv.2020.138813.

6. Gorrasi, G., Sorrentino, A., Lichtfouse, E. 2020. Back to plastic pollution in COVID times. Environmental Chemistry Letters 1-4. https://doi.org/10.1007/s10311-020-01129-z.

7. IBGE (Brazilian Institute of Geography and Statistics) 2021. Projection of the population of Brazil and the Federal Units. https:// www.ibge.gov.br/apps/populacao/projecao/index.html [in Portuguese]. Accessed 14 Feb 2021.

8. Corporate Commitment to Recycling (CEMPRE). 2019. Review 2019. Brazil: São Paulo (SP). http://cempre.org.br/upload/CEMPRE-Review2019.pdf. Accessed 27 Nov 2020.

9. ANCAT 2020. Recycling Yearbook 2020. https://ancat.org.br/ anuario-da-reciclagem-2020/ [in Portuguese]. Brazil: São Paulo (SP). Accessed 29 Nov 2020.

10. National Sanitation Information System (SNIS) 2019. National System of Information on Water and Sanitation. http://www.snis. gov.br/diagnostico-anual-agua-e-esgotos/diagnostico-dos-servicosde-agua-e-esgotos-2018 [in Portuguese]. Accessed 23 Jun 2020.

11. Silva, S.P. 2017. The collective organization of recyclable material collectors in Brazil: dilemmas and potentialities from the perspective of the Solidarity Economy. Brazil: Rio de Janeiro (RJ). https:// www.ipea.gov.br/portal/images/stories/PDFs/TDs/td_2268.pdf [in Portuguese]. Accessed 29 Nov 2020.

12. ANCAT (2019) Recycling Yearbook 2017-2018. https://ancat.org. br/wp-content/uploads/2019/09/Anua\%CC\%81rio-da-Reciclagem. pdf [in Portuguese]. Accessed 29 Nov 2020

13. Böll, F.H. 2020. Atlas of Plastic 2020. Brazil: Rio de Janeiro (RJ). https://br.boell.org/sites/default/files/2020-11/Atlas\%20do\%20Pl\% C3\%A1stico\%20-\%20vers\%C3\%A3o\%20digital\%20-\%2030\% 20de $\% 20$ novembro\%20de\%202020.pdf [in Portuguese]. Accessed 24 Oct 2020.

14. D'ambrières, W. 2019. Plastics recycling worldwide: Current overview and desirable changes. Field Actions Science Reports. 12-21.

15. Sangkham, S. 2020. Face mask and medical waste disposal during the novel COVID-19 pandemic in Asia. Case Studies in Chemical and Environmental Engineering 2: 100052. https://doi.org/10. 1016/j.cscee.2020.100052.

16. Klemeš, J.J., van, F.Y., Tan, R.R., et al. 2020. Minimising the present and future plastic waste, energy and environmental footprints related to COVID-19. Renewable and Sustainable Energy Reviews. https://doi.org/10.1016/j.rser.2020.109883.

17. Presidência da República 2010. Federal Law n. 12.305. Brazil: Brasília (DF). http://www.planalto.gov.br/ccivil_03/_ato2007-2010/ 2010/lei/112305.htm [in Portuguese]. Accessed 16 Nov 2020.

18. SINIR 2015. Setorial Agreement. https://sinir.gov.br/images/sinir/ Embalagens\%20em\%20Geral/Acordo_embalagens.pdf [in Portuguese]. Accessed 24 Oct 2020.

19. De Sousa, M., Dutra, R., and Harue Yamane, L., et al. 2018. Influence of the expansion of the selective collection in the sorting infrastructure of waste pickers' organizations: a case study of 16 Brazilian cities. Waste Management 77: 50-58. https://doi.org/10. 1016/j.wasman.2018.05.009.

20. Paschoalin Filho, J.A., Ghermandi, A., Guerner Dias, A.J., et al. 2021. Stakeholder views of source separation collection programme in East São Paulo, Brazil. Waste Management \& Research 39: 93-100. https://doi.org/10.1177/0734242X20972774.

21. Conke, L.S. 2018. Barriers to waste recycling development: evidence from Brazil. Resources, Conservation and Recycling 134: 129-135. https://doi.org/10.1016/j.resconrec.2018.03.007.

22. Tsalis, T., Amarantidou, S., Calabró, P., et al. 2018. Door-to-door recyclables collection programmes: willingness to participate and influential factors with a case study in the city of Xanthi (Greece). 
Waste Management \& Research 36: 760-766. https://doi.org/10. 1177/0734242X18764291.

23. ABRELPE (2019) Panorama of Solid Waste in Brazil 2018/2019. Brazil: São Paulo. https://abrelpe.org.br/download-panorama2018-2019/ [in Portuguese]. Accessed 10 Nov 2020

24. Nanda, S., and Berruti, F. 2020. Municipal solid waste management and landfilling technologies: a review. Environmental Chemistry Letters. https://doi.org/10.1007/s10311-020-01100-y.

25. Vaverková, M.D. 2019. Landfill impacts on the environmentreview. Geoscience 9: 1-16. https://doi.org/10.3390/geoscience s9100431.

26. Agamuthu, P., and Law, H.J. 2020. Do we need landfills? Waste Management \& Research 38: 1075-1077. https://doi.org/10.1177/ $0734242 X 20943036$.

27. Brazil 2020. Federal Law n. 14,026/2020. Brazil: Brasília (DF). https://www.in.gov.br/en/web/dou/-/lei-n-14.026-de-15-de-julhode-2020-267035421 [in Portuguese]. Accessed 01 Dec 2020.

28. Brazil (2018) Diagnosis of Urban Solid Waste Management 2018. Brazil: Brasília (DF). http://www.snis.gov.br/diagnostico-anualresiduos-solidos/diagnostico-do-manejo-de-residuos-solidos-urban os-2018 [in Portuguese]. Accessed 10 Nov 2020

29. Brazilian Association of Environmental Engineering and Sanitation (ABES) 2020. Impact of COVID-19 on waste management: find out about the situation in Brazilian capitals. https://www.youtu be.com/watch?v=pWEpJyhTOow [in Portuguese]. Accessed 29 Nov 2020.

30. Brasil, C. 2020. Quarantine increases collection of recyclable materials, according to the association. https://www.cnnbrasil.com.br/ nacional/2020/06/26/quarentena-aumenta-coleta-de-materiaisreciclaveis-segundo-associacao [in Portuguese]. Accessed $10 \mathrm{Sep}$ 2020.

31. Mofijur, M., Fattah, I.M.R., and Alam, M.A., et al. 2021. Impact of COVID-19 on the social, economic, environmental and energy domains: Lessons learnt from a global pandemic. Sustainable Production and Consumption 26: 343-359. https://doi.org/10.1016/j. spc.2020.10.016.

32. Penteado, C.S.G., and de Castro, M.A.S. 2021. COVID-19 effects on municipal solid waste management: What can effectively be done in the Brazilian scenario? Resources, Conservation and Recycling 164: 105152. https://doi.org/10.1016/j.resconrec.2020. 105152.

33. Brazilian Association of Environmental Engineering and Sanitation (ABES) 2020. The impact of pandemia by COVID-19 on the management of urban solid waste situation of Brazilian capital. Brazil: Brasília (DF). http://abes-dn.org.br/wp-content/uploads/ 2020/08/Pesquisa-ABES-2.1-Pandemia-COVID-19-RSU-Capit ais-26.8.2020-2.pdf [in Portuguese]. Accessed 10 Feb 2021.

34. Urban, R.C., and Nakada, L.Y.K. 2021. COVID-19 pandemic: solid waste and environmental impacts in Brazil. Science of the Total Environment 755: 142471. https://doi.org/10.1016/j.scitotenv. 2020.142471.

35. Asia, N. 2020. Plastics pile up as coronavirus hits Asia recyclers. https://asia.nikkei.com/Spotlight/Environment/Plastics-pile-up-ascoronavirus-hits-Asia-recyclers. Accessed 20 Nov 2020.

36. Broke, J. 2020. Plastic pandemic: COVID-19 trashed the recycling dream. https://www.japantimes.co.jp/news/2020/10/06/world/scien ce-health-world/plastic-coronavirus-recycling/. Accessed 30 Oct 2020.

37. Kushwaha, P. 2020. Conceptual Reverse Logistics Model used by Online Retailers Post COVID-19 Lockdown. SAMVAD: SIBM Pune Research Journal 20:28-33.

38. Yu, H., Sun, X., and Solvang, W.D. 2020. Zhao X (2020) Reverse logistics network design for effective management of medical waste in epidemic outbreak: insights from the coronavirus disease 2019 (COVID-19) in Wuhan. International Journal of Environmental
Research and Public Health 17 (5): 1770. https://doi.org/10.3390/ ijerph17051770.

39. Zhou, C., Yang, G., Ma, S., et al. 2021. The impact of the COVID19 pandemic on waste-to-energy and waste-to-material industry in China. Renewable and Sustainable Energy Reviews 139: 110693. https://doi.org/10.1016/j.rser.2020.110693.

40. Kampf, G., Todt, D., Pfaender, S., et al. 2020. Persistence of coronaviruses on inanimate surfaces and their inactivation with biocidal agents. Journal of Hospital Infection 104: 246-251. https://doi.org/ 10.1016/j.jhin.2020.01.022.

41. Ilyas, S., Srivastava, R.R., and Kim, H. 2020. Disinfection technology and strategies for COVID-19 hospital and bio-medical waste management. Science of the Total Environment 749: 141652. https://doi.org/10.1016/j.scitotenv.2020.141652.

42. Mol, M.P.G., and Caldas, S. 2020. Can the human coronavirus epidemic also spread through solid waste? Waste Management \& Research 38: 485-486. https://doi.org/10.1177/0734242X20918312.

43. Borges, M.S., Cruvinel, V.R., de Lira, L.H.P., Martins, A.C.S., Ghosh, S.K. 2018. Socioeconomic and demographic profile of waste pickers in Brazil and India. Waste Management and Resource Efficiency 263-273. https://doi.org/10.1007/978-981-10-7290-1_23

44. Staub C (2020) City data shows COVID-19 impacts on recycling tonnages. https://resource-recycling.com/recycling/2020/ 04/28/city-data-shows-covid-19-impacts-on-recycling-tonnages/. Accessed 4 Dec 2020.

45. Ontario Waste Management Association (OWMA) 2020. The impact of COVID-19 on curbside recycling. https://www.owma. org/cpages/covid. Accessed 4 Dec 2020.

46. Interreg Europe (IE) 2020. COVID-19: The impact of the pandemic on the waste sector. https://www.interregeurope.eu/polic ylearning/news/9076/covid-19-the-impact-of-the-pandemic-onthe-waste-sector/. Accessed 4 Feb 2020.

47. Portman, R., Stabenow, D. 2019. RECYCLE Act. USA. https:// www.portman.senate.gov/sites/default/files/2019-11/RECYCLE\% 20Act.pdf. Accessed 09 Dec 2020.

48. Crunden, E.A., Rosengren, C. 2020. Tracking the future of US recycling policy in Congress. https://www.wastedive.com/news/ tracking-the-future-of-us-recycling-policy-in-congress/570778/. Accessed 10 Dec 2020.

49. EC 2020. Waste management in the context of the coronavirus crisis. https://ec.europa.eu/info/sites/info/files/waste_management_ guidance_dg-env.pdf Accessed 09 Dec 2020.

50. Campos, H.K.T. 2014. Recycling in Brazil: challenges and prospects. Resources, Conservation and Recycling 85: 130-138. https://doi.org/10.1016/j.resconrec.2013.10.017.

51. Egun, N.K., and Evbayiro, O.J. 2020. Beat the plastic: an approach to polyethylene terephthalate (PET) bottle waste management in Nigeria. Waste Disposal \& Sustainable Energy 2: 313-320. https:// doi.org/10.1007/s42768-020-00052-x.

52. Fan, K.-S., Lin, C.-H., and Chang, T.C. 2005. Management and performance of taiwan's waste recycling fund. Journal of the Air and Waste Management Association 55: 574-582. https://doi.org/ 10.1080/10473289.2005.10464647.

53. Azevedo, B.D., Scavarda, L.F., Caiado, R.G.G., et al. 2021. Improving urban household solid waste management in developing countries based on the German experience. Waste Management 120: 772-783. https://doi.org/10.1016/j.wasman.2020.11.001.

54. Sarkis, J., Cohen, M.J., Dewick, P., et al. 2020. A brave new world: lessons from the COVID-19 pandemic for transitioning to sustainable supply and production. Resources, Conservation and Recycling 159: 104894. https://doi.org/10.1016/j.resconrec.2020.104894.

55. Adyel, T.M. 2020. Accumulation of plastic waste during COVID-19. Science 369: 1314-1315. https://doi.org/10.1126/science.abd9925.

Publisher's Note Springer Nature remains neutral with regard to jurisdictional claims in published maps and institutional affiliations. 